\title{
POSSIBILITIES OF IMPLEMENTATION AND BENEFITS OF POLYTECHNIC EDUCATION IN TERMS OF SECONDARY SCHOOLS WITH HUMANITIES AND/OR SCIENCES FOCUSED PROGRAMS
}

Milan KLEMENT*, Univerzita Palackého v Olomouci

Přijato: 16. 2. 2015 / Akceptováno: 25. 5.2015

Typ článku: Výzkum

DOI: $10.5507 /$ jtie.2015.003

Abstract: Polytechnic education in terms of non-technical schools represents a new, relatively unexplored area. It is therefore necessary to deal with questions concerning the necessity of such training at these schools, and its potential influence and/or inpact on students` further development.

nder, was the explanation of the benefits of an experiment, focused on the addition of a thematic unit of computer aided design (drafting) in $2 D$ and $3 D$ supported by CAD systems to the curriculum of non-technical secondary schools.

Key words: polytechnic education, pedagogical experiment, CAD system.

\section{MOŽNOSTI REALIZACE A PŘÍNOSY POLYTECHNICKÉHO VZDĚLÁVÁNÍ V PODMÍNKÁCH HUMANITNĚ A PŘÍRODOVĚDNĚ ORIENTOVANÝCH STŘEDNÍCH ŠKOL}

Resumé: Polytechnické vzdělávání je v podmínkách netechnicky orientovaných škol novou, relativně neprobádanou oblastí. Je tedy nutné zabývat se otázkami, zda je tato výuka na těchto školách potřebná a jaký může mít dopad na další rozvoj studentü.

Účelem realizované výzkumné práce, jež je prezentována $v$ dalším textu, byla explanace prínosů provedeného experimentu, který spočival v zavedeni tematického celku počitačem podporované vytváreni $2 D$ a $3 D$ výkresové dokumentace s podporou CAD systému do výuky netechnicky orientovaných středních škol.

Klíčová slova: Polytechnické vzdělávání, pedagogický experiment, CAD systém.

*Autor pro korespondenci: milan.klement@upol.cz 


\section{1 Úvod}

Technika je součástí našeho života, je všude kolem nás. Lze konstatovat, že člověk bez potřebných základních technických vědomostí a dovedností by v současné době nemohl kvalitně plnit svoji společenskou funkci a vést plnohodnotný život (Zubatá, Plishke, Kropáč, 2011). Vzdělávací systém tedy musí zpř́stupnit celé populaci, nejen tedy studentům technicky orientovaných škol, elementární technické vědomosti a dovednosti. Toto elementární technické vzdělávání je ve vyspělých školských systémech nedílnou součástí základního všeobecného vzdělávání, které se uskutečňuje na základních i středních školách. Děje se tak prostřednictvím vyučovacích předmětu, které mají u nás i v zahraničí nejen různé názvy (pracovní vyučování, pracovní výchova, technická výchova, technická praktika, technické práce, technika, praktické činnosti, technologie apod.), ale i rozsah a obsah. V posledních letech je v odborné literatuře často používán termín „vyučovací předměty technického charakteru“ (Idrus, Mond, Abdullah, 2010). Žáci jsou jejich prostřednictvím vybavováni nejen teoretickými poznatky, ale i elementárními pracovními dovednostmi. Důraz je zpravidla kladen na technickou tvořivou činnost podle zájmu žáku (převážné ve volitelných předmětech). Pres rychlý rozvoj výpočetní techniky je ve všech vzdělávacích systémech vyspělých zemí zachována i elementární manuální pracovní činnost technického charakteru (obrábění dřeva, kovu, práce s nástroji a jednoduchými stroji, elektromontážní práce apod.), ale stále častěji se setkáváme s propojením obou oblastí. Cílem technické, respektive polytechnické výchovy a vzdělávání je rozvinout u vzdělávaných dovednosti v zacházení s pracovními nástroji a stroji, osvojit pracovní kulturu a seznámit je s vědeckými principy soudobé výroby, pravidly bezpečnosti práce apod. (Mojžíšek, 1981). V současnosti jsou tyto cíle dále rozvinuty o oblast využití ICT pro podporu těchto činností, nebot' informační technologie dnes pokrývají či podporují značnou část průmyslové produkce. $\mathrm{V}$ technicky zaměřených předmětech, kdy dochází ke kombinaci obou výše uvedených segmentů cílů, může být tento úkol dobře plněn, jejich obsah i procesní stránka je blízká výkonům řady profesí, dnes nejen profesí označovaných jako technické (Manullang, Kons, 2012).

I přesto, že výuka na základních a středních školách je primárně zaměřena na všeobecnou př́ípravu, stává se př́íprava k použití výpočetní techniky a techniky obecně stále významnější složkou vzdělávání (Granath, 2003, p. 129). Tyto snahy jsou nejen deklarovány, ale zakotveny také $\mathrm{v}$ celé řadě kurikulárních či koncepčních dokumentů $\mathrm{a} v$ řadě př́ípadů jsou také finančně podporovány $\mathrm{z}$ různých dotačních titulů. Výše uvedené skutečnosti tedy naznačují, že pozornost vzdělávacích systémů je jednoznačně napřena směrem $\mathrm{k}$ podpoře polytechnického vzdělávání. Bohužel minimálně $\mathrm{v}$ podmínkách českého vzdělávací soustavy tomu vždy tak není. V průběhu let 2006 a 2007 totiž provedla fakulta informatiky a statistiky VŠE v Praze a společnosti CACIO-ČSSI-SPIS komplexní výzkum s cílem analyzovat připravenost studentů všeobecných gymnázií na odborné studium na technických VŠ. Průzkumu se účastnilo 53 fakult v ČR. Závěry této studie jsou alarmující: upozorňují na nedostatek odborníků v oblasti technických oborů, dále na nedostatečné odborné znalosti pedagogických pracovníků, nedostatečnou úroveň vzdělání na všeobecných gymnáziích $\mathrm{v}$ oblasti technických disciplín založených na základech vytváření výkresové dokumentace, jakožto jednoho $\mathrm{z}$ velmi důležitých předpokladů úspěšného studia na technických vysokých školách. Pouze malá část studentů víceletých gymnázií také pokračuje ve studiu na technických vysokých školách a preferují více humanitně zaměřená studia. 
Přitom jejich předpoklady ke studiu na technických vysokých školách jsou velmi dobré (matematika, chemie, fyzika apod.). Na základě těchto výsledků byl autorem tohoto článku proveden podobný výzkum také v roce 2013 (Klement, Kubrický, 2013). V rámci tohoto výzkumného šetření, jehož část probíhala na 6-ti víceletých gymnáziích, byla také zkoumána otázka, proč studenti víceletých gymnázií jen velmi málo hlásí na technicky orientované vysoké školy. Ti nejčastěji na položený dotaz reagovali tvrzením, že nejsou schopni vyhodnotit př́nosy studia na takto orientované vysoké škole, nebot' $\mathrm{v}$ rámci jejich studia na víceletém gymnáziu neabsolvují žádný předmět, který by jim problematiku techniky a technologií alespoň částečně přiblížil.

Na základě těchto výsledků jsme tedy v roce 2013 začali připravovat a v roce 2014 realizovat experiment, kdy $\mathrm{v}$ rámci výuky informatických předmětů na víceletých gymnáziích, byl do výuky zařazen tematický celek „Aplikace matematiky a chemie v technickém počítačovém kreslení“, který integroval jak oblast technického kreslení a vytváření výkresové dokumentace, ale také oblast využití specializovaných softwarových prostředků CAD pro tyto činnosti (Klement, 2001). Experiment byl tedy zaměřen na zavedení tematického celku „Aplikace matematiky a chemie $\mathrm{v}$ technickém počítačovém kreslení do výuky víceletých gymnáziích a vyhodnocení dopadu takto koncipovaného vzdělávání na studenty.

\section{Prostorová představivost a její rozvoj}

Prostorová představivost každého $\mathrm{z}$ nás doprovází po celý život a na každém kroku, i když si to většina $z$ nás ani neuvědomuje. Prostorová orientace se začíná vyvíjet již v kojeneckém věku, kdy se dítě učí sledovat dráhu pohybujících se předmětů a orientovat se v nejbližším okolí. Vývoj začíná ve směru vertikálním, kdy si dítě díky zemské přitažlivosti osvojuje pojmy nahoře - dole. Následuje pohyb předozadní a horizontální. Zdokonalování a prohlubování vnímání pak probíhá po celý náš život. O představivosti nemůžeme říct, že se jedná výhradně o schopnost matematickou, či psychologickou. Jsou však obory lidské činnosti, ve kterých bychom se bez rozvinuté prostorové představivosti vůbec neobešli - máme na mysli např́íklad sochařství, topologii, architekturu, stavitelství a dalši technické obory.

Prostorovou predstavivostí se podle Jirotkové (1990) rozumí intelektová schopnost dovednost cíleně si vybavovat:

- dříve viděné - vnímané objekty $\mathrm{v}$ trojrozměrném prostoru a vybavit si jejich vlastnosti, polohu a prostorové vztahy,

- dříve nebo $\mathrm{v}$ daném momentě viděné - vnímané objekty $\mathrm{v}$ jiné vzájemné poloze, než v jaké byly nebo jsou skutečně vnímány,

- objekt v prostoru na základě jeho rovinného obrazu,

- neexistující reálný objekt $\mathrm{v}$ trojrozměrném prostoru na základě jeho slovního popisu.

Prostorová představivost se rozvíjí v souvislosti s rozvojem některých dovedností, jako:

- komunikovat (zejména grafická komunikace),

- používat pomůcky a rysy,

- pracovat s matematickými a technickými pojmy,

- aplikovat matematické a technické poznatky, 
- objevovat a pracovat tvořivě.

Prostorová představivost nám může sloužit $\mathrm{k}$ různým účelům. Může nám být užitečným nástrojem, pomocným způsobem myšlení, cestou k získání informací, způsobem formulace úkolů nebo prímo prostř̌edkem, kterým lze určitý problém vyřešit. Díky všestrannému využití a použití prostorové představivosti existuje velké množství různých definic tohoto slovního spojení. Je samozřejmé, že jinak bude pojem definovat psycholog, jinak neurolog a jiný bude pohled pedagoga či technika. Zřejmě nejširší definici tohoto pojmu poskytl profesor pedagogických věd H. Gardner (1999): „Jádrem prostorové predstavivosti jsou schopnosti, které zajištuji přesné vnímáni vizuálního světa, umožñui transformovat a modifikovat pưvodní vjemy a vytvárejí z vlastni vizuální zkušenosti myšlenkové predstavy, $i$ když už žádné vnějši podněty nepuisobi“".

Právě většinu zmiňovaných účelů prostorové představivosti využíváme v matematice při řešení různých úloh, $v$ chemii při vizualizaci chemických vazeb, př̀i technickém kreslení a konstruování těles, tvarů a objekti̊. Výuka technického kreslení či počítačem podporovaného technického kreslení tak nabízí vhodné podmínky pro rozvoj prostorové představivosti a technického myšlení (Kropáč, 2004). Aby tedy bylo možné sestavovat, a vhodně projektovat výuku tvorby $2 \mathrm{D}$ a $3 \mathrm{D}$ výkresové dokumentace postavenou na využití moderních elektronických studijních materiálů je nutné průběžně zjištovat její dopady na cílovou skupinu a průběžně zjištovat její názory a postoje. Na základě provedených šetření je možné korigovat některé nežádoucí vlivy či je možné akcentovat ty pozitivní. Výuka počítačem podporovaného technického kreslení, podpořená vhodně uspořádanými vzdělávacími materiály tedy skýtá řadu možností pro zefektivnění výuky a rozvoj mezipředmětových vazeb (Grecmanová, 2000).

\section{Př́prava podmínek pro realizaci experimentu}

Nezbytnou podmínkou pro realizaci celého experimentu, bylo vytvoření vlastní koncepce a obsahu výuky, zaměřené na využití systémů CAD, pro rozšíření výuky matematiky a chemie na víceletých gymnáziích o oblast praktické aplikace za využití počítačem podporovaného technického kreslení. Pomocí vytvořeného tematického celku "Aplikace matematiky a chemie $\mathrm{v}$ technickém počítačovém kreslení" mělo dojít jednak $\mathrm{k}$ rozvinutí mezipředmětových vazeb, provázanosti mezi teorií a praktickým uplatněním na reálných príkladech a úlohách z praxe (Grecmanová, 2000), ale také $\mathrm{k}$ podstatnému rozvoji kompetencí studentů $\mathrm{v}$ oblasti počítačem podporovaného technického kreslení (Klement, 2003), jakožto jednoho $z$ důležitých faktorů při jejich případném dalším studiu na technicky zaměřené vysoké škole.

Tímto způsobem mohlo dojít $\mathrm{k}$ podstatnému rozvinutí mezipředmětových vazeb mezi matematikou a chemií a to na základě praktického využití znalostí studenti̊ $\mathrm{z}$ uvedených předmětů při vizualizaci objektů ve $2 \mathrm{D}$ a $3 \mathrm{D}$ prostoru s přesahem do problematiky technického kreslení, jako jednoho ze základních prostředků grafické komunikace. Jednalo se zejména o praktickou aplikaci těchto témat:

- rovinné geometrie (rovnoběžky, mimoběžky apod.),

- prostorové geometrie (prostorová tělesa a plochy, kuželosečky apod.),

- booleovské algebry (operátory and, or, xor, non a jejich grafická vizualizace),

- deskriptivní geometrie (stopy rovin, průniky rovin, řezy těles),

- vizualizace atomární stavby hmoty (vizualizace struktury jádra a valenčních sfér), 
- modelování molekul prvků (vizualizace molekulární stavby),

- modelování molekul sloučenin (vizualizace molekulárních vazeb),

- apod.

Aby bylo možné výše uvedený experiment realizovat, byl podán, schválen a realizován společný projekt Katedry technické a informační výchovy PdF UP v Olomouci a 6-ti partnerských víceletých gymnázií olomouckého kraje s názvem: CAD - počítačem podporované technické kreslení do škol. Cílem tohoto projektu je rozšsiření obsahu výuky matematiky a chemie o problematiku praktické aplikace $\mathrm{v}$ oblasti počítačem podporovaného technického kreslení a to pro 2 . nebo 3. ročník čtyřletého studia studijního oboru 79-41-K/41 Gymnázium nebo pro ekvivalentní ročníky studijních oborů 79-41-K/61 (délka studia 6 let) a 79-41-K/81 (délka studia 8 let). Projekt byl založen na aktivním př́stupu pedagogů (metodiků) $\mathrm{k}$ tvorbě a implementaci nové náplně a aplikace předmětů, tvorbě nového výukového programu, včetně jeho ověřování v př́mé výuce. Jednotlivé klíčové aktivity v sobě také zahrnovaly všechny základní procesy spojené $\mathrm{s}$ obsahovou změnou učebních plánů předmětů zaměřených na praktickou aplikaci a využití počítačem podporovaného technického kreslení pro výuku matematiky a chemie.

Vzhledem $\mathrm{k}$ činnostnímu pojetí realizované výuky, které vycházelo z potřeb víceletých gymnázií, se jako optimální jevila praktická aplikace poznatků na konkrétní př́ílady, včetně vytváření $2 \mathrm{D}$ a $3 \mathrm{D}$ vizualizací, které studentům umožnily lépe pochopit probíranou látku (Klement, 2013a). Takto pojatá koncepce zaručovala, že studenti budou schopni skutečně prakticky aplikovat získané poznatky na reálných př́kladech. Na tomto místě je nutné podotknout, že složení jednotlivých témat bylo zaměřeno především na zvládnutí těch znalostí a dovedností, které jsou bezprostředně nutné pro základní orientaci v oblasti vytváření 2D a 3D výkresové dokumentace v systému AutoCAD 2013 (Klement 2013b). Dále tedy uvádíme konkrétní obsah tematického celku „Aplikace matematiky a chemie $\mathrm{v}$ technickém počítačovém kreslení“.

\begin{tabular}{|c|c|}
\hline $\begin{array}{c}\text { Název výukového } \\
\text { modulu }\end{array}$ & Obsah výukového modulu \\
\hline $\begin{array}{l}\text { Výukový modul 01: } \\
\text { Aplikace matematiky: } \\
\text { základy rovinné } \\
\text { geometrie }\end{array}$ & $\begin{array}{l}\text { Modul seznamuje studenty se základy obsluhy a použití uživatelského } \\
\text { rozhraní aplikace AutoCAD 2013. Pomocí cvičných př́kladů jsou } \\
\text { studenti postupně seznamováni s jednotlivými částmi rozhraní a funkcí } \\
\text { AutoCADu } 2013 \text { a seznamují se také s tvorbou základních rovinných } \\
\text { geometrických obrazců. }\end{array}$ \\
\hline $\begin{array}{l}\text { Výukový modul } 02: \\
\text { Aplikace matematiky: } \\
\text { tvorba a základní } \\
\text { úprava geometrických } \\
\text { obrazců }\end{array}$ & $\begin{array}{l}\text { Modul seznamuje studenty s dalšími možnostmi obsluhy a použití } \\
\text { uživatelského rozhraní aplikace AutoCAD 2013. Pomocí cvičných } \\
\text { př́ikladů jsou studenti postupně seznamováni s dalšími částmi } \\
\text { uživatelského rozhraní aplikace AutoCAD a seznamují se také } \\
\text { s tvorbou a úpravou dalších základních rovinných geometrických } \\
\text { obrazců. }\end{array}$ \\
\hline $\begin{array}{l}\text { Výukový modul 03: } \\
\text { Aplikace matematiky: } \\
\text { tvorba a pokročilejší } \\
\text { úprava rovinných } \\
\text { obrazců }\end{array}$ & $\begin{array}{l}\text { Modul navazuje na poznatky získané v předchozím výukových } \\
\text { modulech } 01 \text { a } 02 \text { a rozšiřuje je o možnosti úprav rovinných } \\
\text { geometrických obrazců pomocí pokročilejších modifikací. Jsou tedy } \\
\text { postupně seznamování, jak ve frontální části výuky, tak i při } \\
\text { samostatné práci s praktickým použitím těchto pokročilejších možností } \\
\text { modifikací. }\end{array}$ \\
\hline
\end{tabular}


Výukový modul 04: Aplikace matematiky: tvorba a pokročilá úprava rovinných obrazců

Výukový modul 05: Aplikace matematiky: označování rozměrů rovinných obrazců

Výukový modul 06: Aplikace matematiky: vyplňování rovinných obrazců

Výukový modul 07: Aplikace matematiky: základy prostorové geometrie

Výukový modul 08: Aplikace chemie: vizualizace sloučenin a prvků v prostoru

Výukový modul 09: Aplikace matematiky: booleovské operace $\mathrm{v}$ prostoru

Výukový modul 10: Aplikace matematiky: rotování a vysunování $\mathrm{v}$ prostoru
Modul navazuje na poznatky získané $\mathrm{v}$ předchozím výukových modulech 01,02 a 03 a rozšiřuje je o možnosti úprav rovinných geometrických obrazců pomocí pokročilých modifikací. Jsou tedy postupně seznamování, jak ve frontální části výuky, tak i při samostatné práci s praktickým použitím těchto pokročilých možností modifikací.

Modul je zaměřen na problematiku označování rozměrů rovinných geometrických obrazců. Studenti jsou postupně seznamování se základními př́stupy a principy vytváření kótování rovinných obrazců. Prakticky tyto poznatky aplikují při vytváření přímých i šikmých kót, kót průměrů a poloměrů. Navazují tak na problematiku vyučovanou v rámci matematiky a aplikují ji v prostředí aplikace AutoCAD 2013.

Modul je zaměřen na problematiku vyplování, tedy šrafování, rovinných geometrických obrazců. Studenti jsou postupně seznamování se základními př́stupy a principy vytváření šrafování rovinných obrazců. Prakticky tyto poznatky aplikují při vytváření šrafovaných oblastí a to jak výběrem vnitřních bodů, tak hraničních oblastí.

Výukový modul 07 je zaměřen na seznámení studentů se základy prostorové geometrie a prostorového modelování v systému AutoCAD 2013. Pomocí frontální i samostatné práce vytvářejí základní prostorová tělesa a některé vybrané plochy. Aplikují tak poznatky z matematiky, které rozšiřují o praktickou činnost zaměřenou na modelování 3D prostorových scén a těles.

Modul navazuje na výukový modul 07 a rozšiřuje jek směrem k praktickým aplikacím poznatků $\mathrm{z}$ chemie, zaměřených zejména na vizualizaci chemických prvků a sloučenin. Studenti tedy samostatně a v 3D prostoru vytváŕejí 3D modely atomů a molekul prvků a sloučenin a to z využitím systému AutoCAD 2013.

Modul je zaměřen na praktickou aplikaci booleovských operací v 3D prostoru na tělesech a plochách. Studenti tedy budou seznamování s problematikou použití operací sjednocení, rozdíl a průnik na praktických př́kladech. Naváží tak na problematiku vyučovanou $\mathrm{v}$ rámci matematiky a to konkrétně $\mathrm{v}$ tématu booleovské algebry, kterou budou prakticky aplikovat v systému AutoCAD 2013.

Modul je zaměřen na praktickou aplikaci operací v 3D prostoru pro vytváření prostorových těles a ploch. Studenti tedy budou seznamování s problematikou použití rotace a vysunutí na praktických př́kladech. Naváží tak na problematiku vyučovanou $\mathrm{v}$ rámci matematiky a to konkrétně v tématu transformací $\mathrm{v} 3 \mathrm{D}$ prostoru, kterou budou prakticky aplikovat v systému AutoCAD 2013.

Tabulka 1 - Obsah tematického celku „Aplikace matematiky a chemie v technickém počitačovém kresleni"

Celkově byla výuka tematického celku „Aplikace matematiky a chemie v technickém počítačovém kresleni" rozdělena do 10 samostatných výukových modulů, které na sebe navazovaly. Jednotlivé realizované výukové moduly měly dvouhodinovou výukovou dotaci. Výuka tematického celku probíhala v roce 2014 na 6-ti víceletých gymnáziích po dobu šesti měsíců a celkově ji absolvovalo 301 studenti̊, a na jejich vzdělávání se podílelo celkem 12 pedagogů. Po skončení této výuky bylo možné přistoupit $\mathrm{k}$ vyhodnocení dopadu a výsledků tohoto experimentálního výukového obsahu z pohledu 
studentů i pedagogů. V dalším textu je tedy popsán postup, způsob vyhodnocení a výsledky dopadu z pohledu studentů

\section{Popis podmínek, vzorku a metod vyhodnocení výsledků experimentu}

Po skončení výuky tematického celku „Aplikace matematiky a chemie v technickém počítačovém kreslení“ proběhlo na všech zapojených školách výzkumné šetření, kdy byly zjištovány názory a postoje studentů těchto škol na výuku tohoto tematického celku a jeho reálný dopad na edukační proces na těchto školách. Výzkumného šetření se účastnilo celkem 301 studentů těchto škol, kteř́ absolvovali výuku se zařazeným experimentálním vzdělávacím obsahem.

Jako základní prostředek pro získání dat potřebných pro realizaci výzkumného šetření byl použit dotazník. Ve struktuře klasifikace výzkumných metod patř́ dotazník mezi nepřímé - vyšetřovací metody. Dotazník lze podle N. Ničkoviče charakterizovat jako „měrný prostředek, pomocí kterého se zkoumají mínění lidí o jednotlivých jevech“ (Horák, Chráska, 1983, s. 94-96). Zkoumané jevy se mohou z hlediska jednotlivce (respondenta) vztahovat bud' $\mathrm{k}$ vnějším jevům, nebo $\mathrm{k}$ vnitřním dějům. Pro potřeby výzkumného šetření byl tedy, na základě osobních zkušeností, zkonstruován strukturovaný evaluační dotazník (Gavora, 2000), pomocí kterého bylo možné zjištovat názory či postoje studentů $\mathrm{k}$ výuce tematického celku „Aplikace matematiky a chemie $\mathrm{v}$ technickém počítačovém kreslení“.

Studenti tedy měli možnost anonymně vyplnit dotazník a zaznamenat tak do něj své názory a postoje na jednotlivé dotazníkové otázky. Svůj názor mohli projevit zaškrtnutím pole ANO či NE a to podle svých osobních preferencí či názorů. Popis výzkumného vzorku je uveden v níže uvedené tabulce číslo 2 .

\begin{tabular}{c|c|c}
\hline Pohlaví & Počet respondentů & Počet respondentů v \% \\
\hline chlapci & 122 & $40,5 \%$ \\
\hline dívky & 179 & $59,5 \%$ \\
\hline celkem & $\mathbf{3 0 1}$ & $\mathbf{1 0 0} \%$ \\
\hline \multicolumn{2}{c}{ Tabulka 2 - Struktura výzkumného vzorku }
\end{tabular}

Jako hlavní metoda pro vyhodnocení pořízených výzkumných dat, byl použit test chí-kvadrát (Chráska, 1988), kterým jsme zjišt'ovali závislost výsledků na určitém signifikantním znaku skupiny respondentů, kterým bylo pohlaví. Pro zjištění mocnosti jednotlivých skupin respondentů, kteří odpovídali stejným způsobem, bylo použito základních popisných statistik a jejich vizualizace pomocí tabulek. Pro výpočet byl použit statistický systém Statistica 11 (Klímek, Stříž, Kasal, 2009). V dalším textu jsou uvedeny některé dílči výstupy realizovaného výzkumného šetření, které mělo za cíl zjistit názory a postoje studentů víceletých gymnázií na výuku tematického celku „Aplikace matematiky a chemie $\mathrm{v}$ technickém počítačovém kreslení“ a jeho reálný dopad na edukační proces na těchto školách.

\section{Dílčí výstupy realizovaného výzkumného šetření}

V dalším textu jsou tedy prezentovány výstupy realizovaného výzkumného šetření a to celkem v šesti samostatných oblastech. Každá analýza v sobě zahrnovala výpočet kontingenční tabulky, výpočet procentuálního zastoupení a posouzení závislosti výsledku 
na pohlaví respondentů. Pro jednoduchost a přehlednost jsou všechny tři analýzy zahrnuty do jedné tabulky.

První zkoumanou oblastí byla skutečnost, zda studenty zaujala problematika aplikací AutoCADu 2013. Studenti tedy mohli svou odpovědí sdělit svůj názor na skutečnost, zda považují výuku aplikací AutoCADu 2013 za zajímavou a tvorbu 2D a 3D výkresové dokumentace $\mathrm{z}$ jejich pohledu za př́nosnou. Souhrn výsledků jejich odpovědí je demonstrován níže uvedenou tabulkou číslo 3.

\begin{tabular}{c|c|c|c}
\hline \multicolumn{4}{c}{ Kontingenční tabulka pro: $\mathbf{n}=\mathbf{3 0 1}$} \\
Pearsonưv chí-kvadrát: $\mathrm{p}=0,048454$ \\
\multicolumn{2}{c}{ Zaujala tě problematika počítačem podporované kreslení? } \\
\hline $\begin{array}{c}\text { Pohlaví } \\
\text { respondentů }\end{array}$ & Chlapci & Dívky & $\begin{array}{c}\text { Rádkové } \\
\text { součty }\end{array}$ \\
\hline $\begin{array}{c}\mathrm{Ne}-\text { nezaujala - } \\
\text { četnost }\end{array}$ & 25 & 55 & $80(27 \%)$ \\
\hline $\begin{array}{c}\text { Ano - zaujala - } \\
\text { četnost }\end{array}$ & 97 & 124 & $221(73 \%)$ \\
\hline $\begin{array}{c}\text { V̌sechny skupiny - } \\
\text { četnost }\end{array}$ & 122 & 179 & $301(100 \%)$ \\
\hline
\end{tabular}

Tabulka 3 - Zaujetí pro výuku počitačem podporovaného kreslení

Dle zjištěných výsledků, uvedených $\mathrm{v}$ tabulce číslo 3 je možné konstatovat, že téměř tři čtvrtiny studentů víceletých gymnázií, konkrétně $73 \%$, výuka aplikací AutoCADu 2013 zaujala. Ukázalo se tedy, že výchozí předpoklad spočívající v tom, že zařazení tohoto experimentálního výukového obsahu bude pro studenty zajímavé a př́nosné se tímto potvrdil.

Dále je možné konstatovat, že existuje statisticky významný rozdíl ( $\mathrm{p}=0,048454)$ mezi četnostmi odpovědí dívek a chlapců. Chlapce zaujala problematika aplikací AutoCADu 2013 prokazatelně více než dívky, což je s ohledem na obecně větší oblíbenost technicky zaměřených činností u chlapců, výsledek obvyklý a nevymykající se obvyklému průměru.

Další zkoumanou oblastí byla skutečnost, zda studenti považují výuku aplikací AutoCADu 2013 za obtížnou, respektive obtižnější než jiné činnosti zaměřené na využití ICT. Studenti tedy mohli svou odpovědí sdělit svůj názor na skutečnost, zda považují výuku tohoto tematického celku za obtížnější než ostatní látku vyučovanou v rámci předmětů zaměřených na ICT či na matematiku a chemii. Souhrn výsledků jejich odpovědí je demonstrován níže uvedenou tabulkou číslo 4.

Kontingenční tabulka pro: $\mathbf{n}=\mathbf{3 0 1}$

Pearsonův chí-kvadrát: $\mathrm{p}=0,070579$

Připadala ti výuka počítačem podporovaného kreslení obtížná?

\begin{tabular}{c|c|c|c}
\hline $\begin{array}{c}\text { Pohlaví } \\
\text { respondentů }\end{array}$ & Chlapci & Dívky & $\begin{array}{c}\text { Rádkové } \\
\text { součty }\end{array}$ \\
\hline $\begin{array}{c}\mathrm{Ne}-\text { nepřipadala - } \\
\text { četnost }\end{array}$ & 96 & 124 & $220(73 \%)$ \\
\hline $\begin{array}{c}\text { Ano- připadala - } \\
\text { četnost }\end{array}$ & 26 & 55 & $81(27 \%)$ \\
\hline
\end{tabular}




\begin{tabular}{c|c|c|c}
\hline $\begin{array}{c}\text { Všechny skupiny - } \\
\text { četnost }\end{array}$ & 122 & 179 & $301(100 \%)$ \\
\hline \multicolumn{4}{c}{ Tabulka 4 - Míra obtižnosti výuky aplikaci AutoCADu 2013 }
\end{tabular}

Dle zjištěných výsledků, uvedených v tabulce číslo 4 je naprosto zřejmé, že drtivé většině studentů víceletých gymnázií nepřipadá výuka aplikací AutoCADu 2013 jako obtížná, respektive obtížnější než ostatní tematické celky zaměřené na ICT či na matematiku a chemii. Tento výsledek poukazuje, mimo jiné na to, že obecná oblíbenost př́rodovědně orientovaných předmětů je nízká a studenti proto vítají každou možnost, jak jejich výuku obohatit, což se také potvrdilo i v tomto př́ípadě.

Dále je možné konstatovat, že existuje statisticky významný rozdíl $(\mathrm{p}=0,070579)$ mezi četnostmi odpovědí dívek a chlapcủ, kdy dívky statisticky významně více vítali zařazení experimentálního výukového obsahu do výuky, protože jeho obtižnost jim připadala nižší.

Třetí zkoumanou oblastí byla skutečnost, zda by studenti přivítali možnost se dále vzdělávat voblasti tvorby $2 \mathrm{D}$ a $3 \mathrm{D}$ výkresové dokumentace $\mathrm{s}$ využitím systému AutoCAD 2013 a to jak řízeně, tak i samostatně. Studenti tedy mohly vyjádřit svůj názor na to, zda jim tato problematika připadala natolik poutavá a rozvíjející, že by se jí rádi zabývali i v budoucnu. Souhrn výsledků jejich odpovědí je demonstrován níže uvedenou tabulkou číslo 5 .

\begin{tabular}{c|c|c|c}
\hline \multicolumn{4}{c}{ Kontingenční tabulka pro: $\mathbf{n}=\mathbf{3 0 1}$} \\
Pearsonův chí-kvadrát: $\mathrm{p}=0,002095$ \\
Chceš se i nadále věnovat počítačem podporovanému kreslení? \\
\hline $\begin{array}{c}\text { Pohlaví } \\
\text { respondentů }\end{array}$ & Chlapci & Dívky & $\begin{array}{c}\text { Rádkové } \\
\text { součty }\end{array}$ \\
\hline $\begin{array}{c}\text { Ne - nechci - } \\
\text { četnost }\end{array}$ & 70 & 133 & $203(67 \%)$ \\
\hline $\begin{array}{c}\text { Ano-chci - } \\
\text { četnost }\end{array}$ & 52 & 46 & $98(33 \%)$ \\
\hline $\begin{array}{c}\text { V̌sechny skupiny - } \\
\text { četnost }\end{array}$ & 122 & 179 & $301(100 \%)$ \\
\hline
\end{tabular}

Tabulka 5 - Zájem o dalši tvorbu výkresové dokumentace s využitím systému AutoCAD

Dle zjištěných výsledků, uvedených $\mathrm{v}$ tabulce číslo 5 je naprosto zřejmé, že pouze necelá třetina studentů, konkrétně $33 \%$, by se ráda dále vzdělávala v problematice tvorby 2D a 3D výkresové dokumentace s využitím systému AutoCAD 2013. tento výsledek je sice $\mathrm{v}$ rozporu s první uvedenou analýzou týkající se zaujetí pro tuto výuku, ale je možné jej vysvětlit tím, že obecná míra intencionality ve vzdělávání je v současnosti nižší a tudíž další vzdělávání je z pohledu studentů odmítáno.

Dále je možné konstatovat, že existuje statisticky významný rozdíl $(\mathrm{p}=0,002095)$ mezi četnostmi odpovědí dívek a chlapcủ, kdy dívky další vzdělávání v oblasti aplikací AutoCADu 2013 odmítají častěji než chlapci. I tento výsledek není nikterak neobvyklý a souvisí $\mathrm{s}$ obecně nižší oblibou technicky a prírodovědně orientovaných předmětů u dívek.

Další zkoumanou oblastí byla skutečnost, zda studenti využijí výstupy výuky aplikací AutoCADu 2013při svém dalším vzdělávání. U studentů, kteří by uvažovali o dalším vzdělávání $\mathrm{v}$ technických oborech, by se dalo předpokládat, že tuto potřebu budou 
preferovat. $\mathrm{Na}$ základě této analýzy se dá tedy usuzovat i na zájem studentů o další technické vzdělávání. Souhrn výsledků jejich odpovědí je demonstrován níže uvedenou tabulkou číslo 6.

\section{Kontingenční tabulka pro: $\mathbf{n}=\mathbf{3 0 1}$}

Pearsonův chí-kvadrát: $\mathrm{p}=0,002431$

Myslíš si, že problematiku počítačem podporovaného kreslení využiješ v dalším vzdělávání?

\begin{tabular}{c|c|c|c}
\hline $\begin{array}{c}\text { Pohlaví } \\
\text { respondentů }\end{array}$ & Chlapci & Dívky & $\begin{array}{c}\text { Rádkové } \\
\text { součty }\end{array}$ \\
\hline $\begin{array}{c}\text { Ne - nevyužiji- } \\
\text { četnost }\end{array}$ & 68 & 130 & $198(66 \%)$ \\
\hline $\begin{array}{c}\text { Ano - využiji - } \\
\text { četnost }\end{array}$ & 54 & 49 & $103(34 \%)$ \\
\hline $\begin{array}{c}\text { Všechny skupiny - } \\
\text { četnost }\end{array}$ & 122 & 179 & $301(100 \%)$ \\
\hline
\end{tabular}

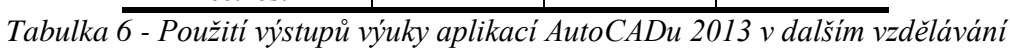

Dle zjištěných výsledků, uvedených v tabulce číslo 6 je zřejmé, že studenti chápou potřebu výuku aplikací AutoCADu 2013 pro tvorbu 2D a 3D výkresové dokumentace, protože $34 \%$ z nich uvedlo, že budou tuto problematiku potřebovat v dalším vzdělávání. Nepř́mo je také možné odvodit, že zájem o technické obory, kde je problematika využití CAD systémů často využívána, je relativně vysoká.

Dále je možné konstatovat, že existuje statisticky významný rozdíl $(p=0,002431)$ mezi četnostmi odpovědí dívek a chlapců, kdy chlapci vnímají problematiku využití CAD systémů pro jejich další studium jako důležitější než dívky, což je opět výsledek, který se dal očekávat.

Pátou zkoumanou oblastí byla skutečnost, zda studenti využijí získané kompetence v oblasti tvorby 2D a 3D technické výkresové dokumentace v dalším životě. Tato otázka opět souvisela, byt' nepř́mo z další profesní orientací studentů a zájmem o jejich další působení $\mathrm{v}$ technických odvětvích. Souhrn výsledků jejich odpovědí je demonstrován níže uvedenou tabulkou číslo 7.

\begin{tabular}{|c|c|c|c|}
\hline \multicolumn{4}{|c|}{$\begin{array}{c}\text { Kontingenční tabulka pro: } \mathbf{n}=\mathbf{3 0 1} \\
\text { Pearsonův chí-kvadrát: } \mathrm{p}=0,000381 \\
\text { Myslíš si, že bude pro tvůj další život počítačem podporované } \\
\text { kreslení přínosné? }\end{array}$} \\
\hline $\begin{array}{c}\text { Pohlaví } \\
\text { respondentů }\end{array}$ & Chlapci & Dívky & $\begin{array}{c}\text { Rádkové } \\
\text { součty }\end{array}$ \\
\hline $\begin{array}{c}\mathrm{Ne}-\text { nebude } \\
\text { př́nosné - četnost }\end{array}$ & 56 & 119 & $175(58 \%)$ \\
\hline $\begin{array}{c}\text { Ano - bude } \\
\text { př́nosné - četnost }\end{array}$ & 66 & 60 & $126(42 \%)$ \\
\hline $\begin{array}{l}\text { Všechny skupiny - } \\
\text { četnost }\end{array}$ & 122 & 179 & $301(100 \%)$ \\
\hline
\end{tabular}

Tabulka 7 - Př́inos výstupio výuky aplikací AutoCADu 2013 pro dalši život 
Dle zjištěných výsledků, uvedených v tabulce číslo 7 je zřejmé, že studenti chápou potřebu výuky aplikací AutoCADu 2013 spojenou s tvorbou 2D a 3D technické výkresové dokumentace, protože $42 \% \mathrm{z}$ nich uvedlo, že výstupy této výuky využijí $\mathrm{v}$ dalším životě.

I když existuje statisticky významný rozdíl $(\mathrm{p}=0,000381)$ mezi četnostmi odpovědí dívek a chlapců, celkově si dívky i chlapci myslí, že aplikace AutoCADu 2013 pro jejich další život př́nosná není, tak chlapci významně častěji připouštějí, že pro ně tvorba 2D a 3D výkresové dokumentace př́nos bude mít.

Poslední, zde uvedenou, zkoumanou oblastí byla skutečnost, zda si studenti myslí, že na základě studia problematiky vytváření $2 \mathrm{D}$ a $3 \mathrm{D}$ technické výkresové dokumentace v prostředí AutoCADu 2013 nyní lépe chápou principy a způsob fungování výpočetní techniky a softwarového vybavení. Byla tedy zkoumána skutečnost, zda došlo u studentů $\mathrm{k}$ hlubšímu pochopení ostatní probírané látky související s problematikou ICT. Souhrn výsledků jejich odpovědí je demonstrován níže uvedenou tabulkou číslo 8.

\begin{tabular}{c|c|c|c}
\hline \multicolumn{4}{c}{ Kontingenční tabulka pro: $\mathbf{n}=\mathbf{3 0 1}$} \\
Pearsonưv chí-kvadrát: $\mathrm{p}=0,245060$ \\
\multicolumn{2}{c}{ Myslíš si, že nyní lépe chápeš fungování výpočetní techniky? } \\
\hline $\begin{array}{c}\text { Pohlaví } \\
\text { respondentů }\end{array}$ & Chlapci & Dívky & $\begin{array}{c}\text { Ŕádkové } \\
\text { součty }\end{array}$ \\
\hline $\begin{array}{c}\mathrm{Ne}-\text { nechápu lépe } \\
\text { - četnost }\end{array}$ & 51 & 87 & $138(46 \%)$ \\
\hline $\begin{array}{c}\text { Ano - chápu lépe } \\
\text { - četnost }\end{array}$ & 71 & 92 & $163(54 \%)$ \\
\hline $\begin{array}{c}\text { Všechny skupiny - } \\
\text { četnost }\end{array}$ & 122 & 179 & $301(100 \%)$ \\
\hline
\end{tabular}

Tab. 8 Lepši chápáni principů a fungováni výpočetni techniky

Dle zjištěných výsledků, uvedených v tabulce číslo 8 je naprosto zřejmé, že většina studentů nyní chápe principy fungování výpočetní techniky lépe, než tomu bylo před realizací výuky aplikací AutoCADu 2013. Experimentální výukový obsah tedy rozvinul $\mathrm{u}$ studentů znalosti a dovednosti $\mathrm{v}$ oblasti tvorby $2 \mathrm{D}$ a $3 \mathrm{D}$ výkresové dokumentace a souvisejících mezipředmětových vazeb mezi matematikou a chemií, ale rozvinul také hlubší pochopení principů fungování ICT a možností jeho využití.

Dále je možné konstatovat, že neexistuje statisticky významný rozdíl $(\mathrm{p}=0,245060)$ mezi četnostmi odpovědí dívek a chlapců a obě tyto skupiny tedy mají stejný názor.

\section{Závěr}

Výše popsaný experimentální výukový obsah zaměřený na rozšíření výuky matematiky a chemie o problematiku praktické aplikace $\mathrm{v}$ oblasti počítačem podporovaného technického kreslení, představuje inovativní způsob využívání moderních informačních a komunikačních technologií ve vzdělávání. Jeho dopady, jak vyplynulo z výše popsaného výzkumného šetření, pozitivně ovlivnili formování klíčových výukových aktivit pro studenty vyššího sekundárního vzdělávání a zvýšili také kvalifikaci pedagogů víceletých gymnázií, kde byla tato experimentální výuka realizována.

Práce $\mathrm{s}$ moderními a trendovými výukovými prostředky tak nabídla jedinečnou možnost rozvoje klíčových kompetencí učitelů i žáků v relativně málo probádané oblasti 
mezipředmětových vazeb mezi matematikou, chemií, informačními technologiemi a technickými předměty. Př́nosem a přidanou hodnotou pro pedagogy bylo získání nové odbornosti, rozšíření profesních dovedností, výrazné zlepšení podmínek pro př́ípravu a realizaci výuky technicky orientovaných grafických systémů a $\mathrm{v}$ neposlední řadě také volný př́istup $\mathrm{k}$ elektronických vzdělávacím materiálům $\mathrm{z}$ této oblasti.

Studentům experimentální výukový obsah nabídnul možnost seznámit se a zdokonalit se v problematice vytváření $2 \mathrm{D}$ a $3 \mathrm{D}$ výkresové dokumentace $\mathrm{v}$ systému AutoCAD 2013 a rozvíjet tak jednotlivé dovednosti nově, včetně možnosti poutavě a samostatně řešit úkoly v návaznosti na individuální znalosti práce $\mathrm{s}$ ICT, efektivně a tvořivě využívat prostředky komunikace, a přijmout odpovědnost za vlastní práci. Všechny uvedené kompetence společně mohou významně přispět $\mathrm{k}$ širší adaptabilitě studentů při dalším studiu na vysokých školách.

\section{Literatura}

Gavora, P. (2000). Úvod do pedagogického výzkumu. 1. vyd., Brno: Paido.

Granath, J. (2003). Design theoretical approach to learning in technology - a way to enhance interest in future professional studies. In: Teoretyczne $i$ praktyczne problemy edukaci technicznej i informatycznej 2003. Rzeszów: Wydawnictwo Oświatowe FOSZE, s. $128-139$.

Grecmanová, H. (Ed.). (2000). Podporujeme aktivní myšlení a samostatné učení žáků. 1. vyd., Olomouc: Nakladatelství HANEX.

Chráska, M. (1988). Empirická pedagogická šetření a jejich statistické vyhodnocování. 1. vyd., Olomouc: Vydavatelství Univerzity Palackého.

Idrus, H., Mond, D. H., Abdulah, N. (2010). Integratingcriticalthinking and problém solving skills in the teaching of technical courses: Thenarrativeof a Malaysianprivate university. In Engineering Education. KualaLumpur. vol. 5, no. 2. p. 258-263.

Jirotková, D. (1990). Rozvoj prostorové predstavivosti žákủ. In: Komenský č. 5, Praha.

Klement, M. (2003). Grafické programy a multimédia - AutoCAD 2000. 1. vyd. Olomouc: Vydavatelství UP Olomouc.

Klement, M., Kubrický, J. (2013). Možnosti výuky systému AutoCAD 2013 na víceletých gymnáziích. In Trends in Education: Information Technologies and Technical Education. Olomouc, vol. 1. p. 202-209.

Klímek, P., Stř́ž, P., \& Kasal, R. (2009). Počítačové zpracování dat v programu STATISTICA. 1. vyd. Bučovice: Martin Stř́ž.

Kropáč, J. (2004). K problému uceleného pojetí výuky obecně technických předmětů.

In e-Pedagogium, vol. 4, no 1.

Manullang, B. \& Kons, S. M. (2012). Theintegrationof soft skill and hard skill in learning revolution. In Education Technology and Computer. Shanghai, vol. 3, p. 436439.

Mojží̌ek, L. (1981). Pracovni výchova, polytechnické vzdělání a profesionální orientace: Systém a subsystémy pracovni výchovy. Brno: UJEP.

Zubatá, A., Plischke, J., Kropáć, J. (2011). Výuka technických předmětů, zkušenosti žáka a jeho kariérové rozhodování. In XXIV. DIDMATTECH 2011. Kraków. Universytet Pedagogiczny. s. 96-102. 